\title{
A Study on the Policies Concerning the Management of Employment Leak Age in Three Star Hotels in the Greater Cairo Region
}

Ashraf Abd El-Maboud El Hussein Moawad Said Hanan Sayed Lotief Faculty of tourism and hotels Fayoum University

\begin{abstract}
Employee leakage is achieving basic levels for some Hotels chain, which battle to keep up legitimate staffing levels in a tight labour market (WeiBo et al. 2010). Leakage has been a measure of performance in hotels that is costs lots of money related to financial and operational effectiveness. Organizational stability is known to have a high level of relationship with low leakage. Signs are that employees will probably stay when there is an anticipated and stable workplace (Zuber, 2001).

The current study conducted through cross-sectional design to gather primary data in order to determine causes for the high employee leakage in three-star hotels. Data were collected from the professional, supervisory, and managerial staff in these hotels in greater Cairo. Using regression analysis, it was determined that the individual leakage causes and satisfaction was a statistically significant variable when analyzing leakage causes in the current study. Over $25 \%$ of the variation in leakage causes was explained by the components of the survey. This research is important to industry professionals as well as academics to help estimate and decrease staffs' leakage in various sectors of the hospitality industry.

Based on the results obtained, the study showed a set of recommendations such as implementing a career development plan and acknowledging the talents and abilities gained by the hotel workers. Human resource management should offer support to employees and a stable and healthy work environment. One-on-one conferences should be scheduled between workers and their managers.
\end{abstract}

Key words: leakage, retention, three-star hotels.

\section{Introduction}

The hospitality industry often suffers from high staff leakage; although the main challenge for Hotels is staff retention. The cost of recruiting and employing a new staff member is very high, and it takes approximately six months to recruit, induct, and train one. Staff leakage at Egyptian hotels has increased considerably. However, this still negatively affects hotel revenue each year. Staff leakage affects the standard of service provided to guests. It also has an impact on staff job satisfaction, as constantly training new staff adds to the work of more experienced staff, which can be frustrating, especially during peak periods. Leakage refers to the "amount of movement of employees in and out of an organization, and is normally presented in terms of the leakage rate. Tanke (2001) has defined leakage as the movement of employees out of the organization. Carley (1992) stated that employee's leakage implies to the rotation of staffs around the labor market, between hotels, employments and careers. However, leakage costs of many organizations are very high and significantly affect the financial performance of an organization. Direct expenses include selection, recruitment, and training of new individuals. Much time and cost go into this procedure. Indirect expenses include particular things, such as expanded workloads and overtime costs for staffs, and in addition decreased efficiency related to low employee morale. . Evaluated costs fluctuate from from organization to organization. It has been also estimated that, on average, it costs a company one-third of a new hire's annual salary to replace an employee (Willis 2002). 


\section{Review of literature}

Saifuddin et al. (2008) mentioned that high leakage and absenteeism are reported to be related to job dissatisfaction, while low absenteeism is associated with high job satisfaction. Schermerholn (1996) indicated that the assessment of job satisfaction in an organization can build positive results, for example, staff performance and satisfaction, and diminish non-attendance and leakage. Examining the employee or employee's value-perception can help managers to assemble and make workplaces that assistance them to accomplish abnormal amounts of worker satisfaction. The aim of exploring worker job satisfaction is a stage toward making creating a healthy psychological contract for individuals at work.

Taylor (2002) suggested that customers yearn for that personal touch and human encounter with the employees during service. Therefore, it is important to understand and control labor leakage at all levels. According to Kusluvan (2003), one of the major causes of friction between employers and their employees is a real or perceived lack of fairness in the distribution of wages. Job Satisfaction in Hotels

Human resources realized that the principal contact that employees have with an organization after being hired is essential to their achievement in the work environment. Cascio (2002) affirmed that job satisfaction might emerge from a wide range of sources, including levels of role ambiguity, autonomy, quality of supervision, quality of social relationships, and level of support in the workplace. The satisfaction-leakage relationship may likewise be directed by different factors, such as gender or mood. Van Dick et al. (2004) discovered confirmation that hierarchical distinguishing proof anticipated leakage goal yet the relationship was incompletely intervened by job satisfaction.

\section{The Concept of Labor Leakage}

The expression "leakage " is characterized by Wood (1999) as the ratio of the number of employees who have left the organization, divided by the average number of people in that organization during the period under consideration. Either each time a position is cleared in the organization, voluntarily or involuntarily, another worker must be contracted and prepared. This replacement cycle is known as leakage. The term is also often used to measure the relationship of employees in an organization as they leave, regardless of the reason. Employee leakage additionally identifies with the development of human resource inside the organizations where employees move from job to job, through transfer, promotion or relocation (Taylor, 2002).

According to Bolch (2001), work leakage is a critical parameter, which demonstrates the general strength of an industry or a foundation as far as salaries, mechanical relations, working conditions, and other welfare offices gave to the specialists. As per Gupta and Shaw (2001), employee leakage is one of the viewpoints most concentrated in hierarchical research but very little is known regarding to conceivable reasons for leakage among experts. Organizational stability is known to have a high level of relationship with low leakage. Signs are that employees will probably stay when there is an anticipated and stable workplace (Zuber, 2001).

\section{Causes of Labor Leakage}

Organizations today generally recognize the vital contribution that their employees play in conveying the quality services. However, they additionally bend over backward to drive down inside expenses as a major aspect of the value duty. Work leakage is viewed as one zone of cost which can be measured and benchmarked and is viewed as a critical factor when measuring organizational performance, which management can affect (White, 1995). Low work leakage is 
viewed as a benefit in the aggressive war. High work leakage is viewed as an issue to be addressed (Glebbeek and Bax, 2004).

As indicated by Hinkin and Tracey (2000) high workers' leakage rates in the lodging business are not nation particular; this is an overall pestilence. As indicated by Taylor (2002), a few jobs are characteristically more appealing than others. A vocation's appeal will be influenced by numerous qualities, including its tedium, challenge, threat, perceived importance, and ability to evoke a feeling of achievement.

\section{Strategies to Eliminate the Leakage}

Holding capable workers can thus be viewed as a key move made to achieve current hierarchical goals, and particularly for what has to come. To hold abilities, Chiu et al. (2005) additionally says "a winning employee esteem proposition», implying that for an association to interest the workers they need to keep the organization's product and brand must be customized such that it bids to the workers. Even more nearly this interest is about the realness on how the organization is spoken to both remotely and inside in the authoritative culture and its esteems" (Ready et al., 2008).

\section{Objectives}

The purpose of this study is to undertake an empirical approach to investigate the potential relationship between the working satisfaction structure and the organization employee leakage. The primary objectives were defined as follows:

1. To investigate and highlight the causes for high employee leakage at three-star hotels in Greater Cairo, Egypt.

2. To study how to reduce the staff leakage and increase employee retention in three-star hotels Greater Cairo.

\section{Hypotheses}

Hypothesis 1: There's a significant relationship between the individual leakage causes and managerial leakage causes.

Hypothesis 2: There's a significant relationship between the individual leakage causes and the employee level of education and experience.

Hypothesis 3: Managerial leakage causes influenced by the individual leakage causes.

\section{Methods and materials}

Research design

This study was conducted through cross-sectional design to gather primary data. This is the case where the researcher interviews a sample group either individually or as a group to represent the opinions of the whole population. The advantages of this design over other research designs are that the data can be collected within a short period and is less expensive (Gregory, 2014). The independent variables for this study were individual causes satisfaction. The dependent variable was leadership and organizational culture causes.

The study aimed to investigate two research questions related to contemporary human resource management in the hotel industry of Greater Egypt. Two central questions were put to the employees in a sample of three-star hotels in Greater Cairo:

1. What are the causes for the high employee leakage in three-star hotels? 
2. How to reduce the staff leakage and increase employee retention in three- star hotels in greater Cairo?

\section{Target Population}

According to The Egyptian Hotel Guide (2014), there are 36 three-star hotels in Greater Cairo with a total of 5410 employees. Out of the 36 hotels, 7 hotels (constituting a representation of $20 \%$ ) with a total of 541 employees (constituting a representation of 10\%) were sampled to provide the respondents. Mugenda\&Mugenda (2008) explained that in a large population (like the one under study) $10 \%$ of total population or more would be sufficient as a sample study. Out of these 541 employees, 358 were picked to form the target population for the study according to sample size Equation of Stephen Sampson. The hotels selected were evenly distributed within the study area. Greater Cairo was considered appropriate for providing a focal point for the study of factors influencing employee leakage in the hospitality industry.

\section{Sampling Design and Sample Size}

Data were collected from the professional, supervisory, and managerial staff in the three-star hotels in of 2015/2016. The accessible population was defined as professional, supervisory, and managerial staff in all departments who have participated in the study process. The personnel records of the individual departments identified the frame of the accessible population. The list of employee participants was provided directly by each department from their personnel management databases. The total number of eligible personnel in the study was 358 employees. Selection of a random sample from each hotel to receive the survey was proposed by the researcher to the hotel management.

\section{Reliability of the Instruments}

Reliability is a measure of how much research instruments yield reliable outcomes after rehashed preliminaries. It is basically the degree to which test scores are free from measurement errors (Mugenda and Mugenda, 2008; Gall and Borg, 2006). The test - retest method was employed to establish the reliability of the questionnaires. This was done by administering the same instrument to the same group of respondents more than once. (Gregory, 2014).

Table (1) shows a Cronbach's alpha of .78 was found from the pilot test, indicating that the instrument was reliable with a high degree of internal consistency. Because of these positive results, no modifications were made to the instrument.

Table 1. Reliability Statistics

\begin{tabular}{|c|c|c|}
\hline Cronbach's Alpha & Cronbach's Alpha Based on Standardized Items & N of Items \\
\hline .808 & .785 & 44 \\
\hline
\end{tabular}

\section{Data Collection Method}

Data collection method can either be quantitative or qualitative data, quantitative is used as a "synonym for any data collection techniques, such as a questionnaire or data analysis procedure such as graphs and statics, that generates or uses numerical data in contrast qualitative is used as a synonym for any data collection techniques such as an interview or data analysis procedure such as data that generated or use non numerical data" (Judd et al., 1991). 


\section{Data Analysis}

Data were analyzed using descriptive statistics. The statistical package for social sciences (SPSS) version 24 was used to process and analyze the data collected which was then presented in form of frequency tables. This was done according to the variables, which included reward and compensation, labor market, leadership/managerial style, and the organizational culture as the factors influencing the employee leakage in the hospitality industry.

Multiple regression analysis technique was used to calculate factors affecting employee leakage in the hospitality industry since it indicates the individual effect of each independent variable on the dependent variable. It also permits one to analyze a relationship among a large number of variables in a single study (Gall and Borg, 2006). The researcher adopted the following to aid in the interpretation of these scales: 1.50 or less $=$ strongly disagree; $1.51-2.5=$ disagree; $2.51-$ $3.49=$ Neutral $; 3.50-4.49=$ agree $;$ and 4.5 or greater $=$ strongly agree .

\section{Results and discussion}

\section{Individual causes satisfaction}

According to the analysis of table 2, Respondents "Agreed" (item scores item scores between 4.49 - 3.50) with sixteen of the items included in the scale which represent $73 \%$ of total scale contribution "individual causes satisfaction". The items with which they most agreed were "Attractive salary and benefits are the major drivers that would make me stay in my current job, Good working environment is the major driver that would make me stay in or leave my current job, I am not satisfied with the current work load, The work load is divided equally among all the organization employees, I believe that lack of career development is one of the reasons for employees to leave the organization, My organization is not fair in general, There is promotion and appraisal procedure in the organization, I stayed at the current job because I don't have other options, Upper management not allow me to participate in decision making, The relationship between employees and managers is good, Interpersonal relationship between employees is good, my current organization is not impartial for over all benefits of employees, I believe that mismanagement is one of the basic reasons for employees to leave their current job, There are jobs in my department that are affected because of employee Leakage, I feel not secure in my job, and My manager is not sympathetic of my personal problems in the work".

These items indicated that salary, mismanagement, and benefits are the major concern for employees to leave or stay in their job. The previous results revealed that employees are not satisfied with their development plan in three star hotels, and they just stay in their job because they don't have any another options. In addition, they think that there's fairness in work load distribution, but the load itself is too much. This may be due to less of the hiring new staff instead of the people who left.

In addition, respondents "strongly disagreed" (item scores 1.51 or less) with one of the items included in the scale "individual causes satisfaction. The item with which they most strongly agreed were "Unfair rewards and promotion systems would drive me to leave my current job". Additionally, employees "disagreed" (item scores between 2.5 - 1.51) with five of the twentytwo items used to personal reasons for leakage. "Employees who work more are rewarded with better appraisal rate and a promotion, Career development program is available in the organization, job training and career advancement is given in a fair manner, my immediate boss/administration arranges flexible working conditions, and I am provided with necessary tool/resources to complete my job". 
These reached results revealed that upper management should consider the process of design and implementing strategies to reward employee fairly with the goal to attract, motivate and retain those employees that are believed to help facilitate the recognition of hotel goals. Moreover, upper management should permit subordinates to take part in decision-making and give them a considerable degree of autonomy in completing routine work activities. Combining between democratic (subordinates are allowed to participate in decision-making) and directive (subordinates are told exactly how to do their jobs) styles gives management distinct ways to manage and increase employees satisfaction which should limit the leakage rate.

Table (2).Survey Analysis

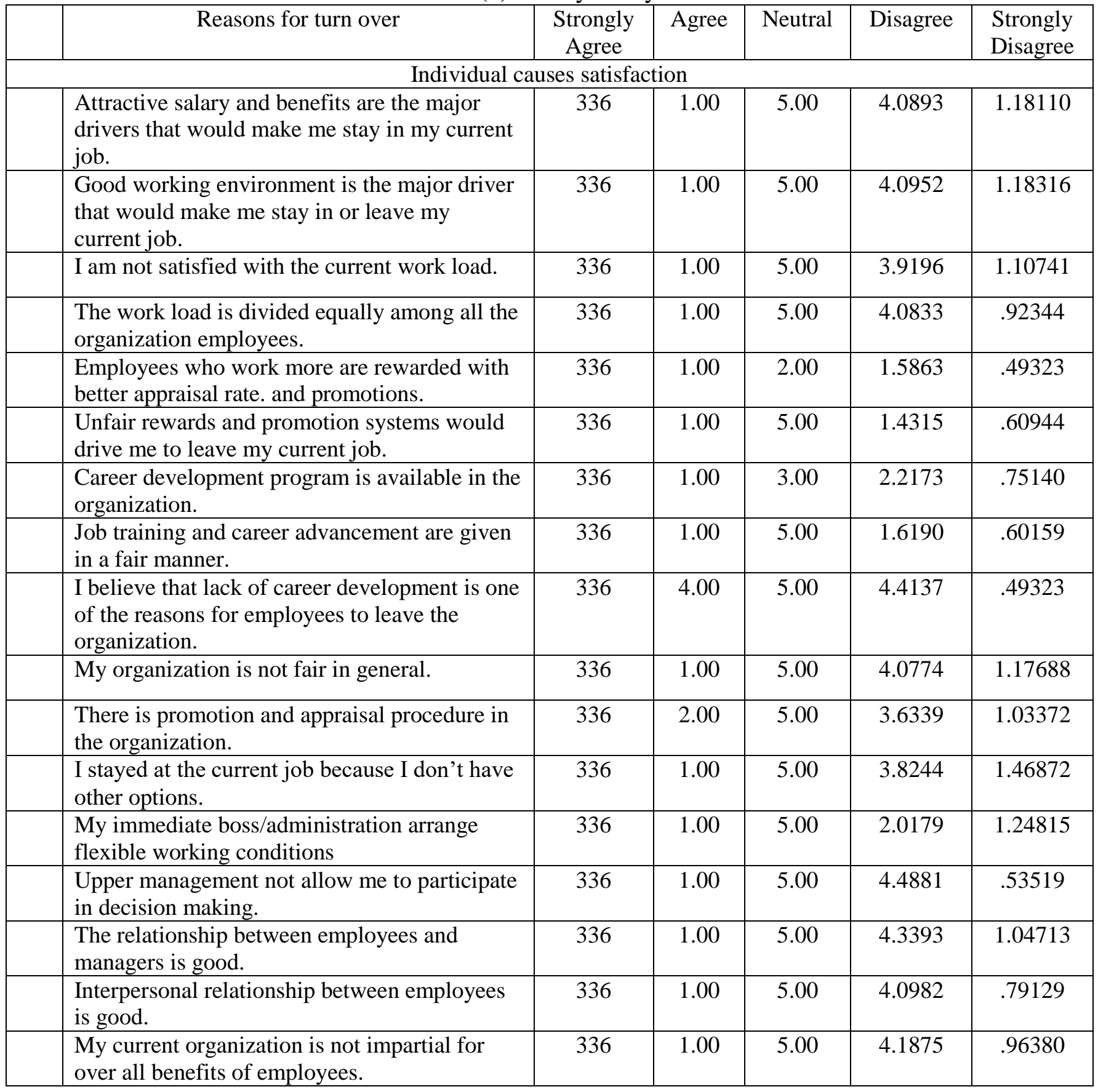


International Journal of Heritage, Tourism and Hospitality Vol. (12), No. (1/2), March, 2018 By: Faculty of Tourism and Hotels, Fayoum University

\begin{tabular}{|c|c|c|c|c|c|}
\hline $\begin{array}{l}\text { I believe that mismanagement is one of the } \\
\text { basic reasons for employees to leave their } \\
\text { current job. }\end{array}$ & 336 & 1.00 & 5.00 & 4.4613 & .56647 \\
\hline $\begin{array}{l}\text { There are jobs in my department that are } \\
\text { affected because of employee leakage. }\end{array}$ & 336 & 1.00 & 5.00 & 3.9405 & .88572 \\
\hline I feel not secure in my job. & 336 & 1.00 & 5.00 & 4.3690 & .70866 \\
\hline $\begin{array}{l}\text { I am provided with necessary tool/resources to } \\
\text { complete my job. }\end{array}$ & 336 & 1.00 & 5.00 & 2.0208 & 1.47097 \\
\hline $\begin{array}{l}\text { My manager is not sympathetic of my personal } \\
\text { problems in the work. }\end{array}$ & 336 & 4.00 & 5.00 & 4.4107 & .49270 \\
\hline Total & & & & 3.595 & 1.290 \\
\hline \multicolumn{6}{|c|}{ Leadership and organizational culture causes } \\
\hline $\begin{array}{l}\text { Managers Have sufficient knowledge of the } \\
\text { job. }\end{array}$ & 336 & 1.00 & 5.00 & 3.0268 & .90564 \\
\hline $\begin{array}{l}\text { Managers acknowledge employees } \\
\text { contribution. }\end{array}$ & 336 & 1.00 & 5.00 & 3.8780 & 1.37569 \\
\hline $\begin{array}{l}\text { Managers not provide constructive feedback } \\
\text { during the appraisal. }\end{array}$ & 336 & 1.00 & 5.00 & 3.9494 & 1.25084 \\
\hline Managers treat employees equally. & 336 & 1.00 & 5.00 & 3.8274 & 1.17434 \\
\hline $\begin{array}{l}\text { Managers maintain a professional relationship } \\
\text { with employees. }\end{array}$ & 336 & 1.00 & 5.00 & 3.8720 & 1.15319 \\
\hline $\begin{array}{l}\text { Managers offer and promote all the ways to } \\
\text { develop his team. }\end{array}$ & 336 & 1.00 & 2.00 & 1.6161 & .48707 \\
\hline $\begin{array}{l}\text { My manager doesn't keep me well informed on } \\
\text { work issues. }\end{array}$ & 336 & 1.00 & 5.00 & 1.5060 & .65560 \\
\hline $\begin{array}{l}\text { My managers neither listen nor valued my } \\
\text { suggestions. }\end{array}$ & 336 & 1.00 & 3.00 & 2.1548 & .77643 \\
\hline My managers use tactful discipline. & 336 & 1.00 & 5.00 & 1.6548 & .71644 \\
\hline $\begin{array}{l}\text { My values aligned with the organization's } \\
\text { culture. }\end{array}$ & 336 & 1.00 & 5.00 & 3.9464 & 1.23510 \\
\hline $\begin{array}{l}\text { Staff development considered with the } \\
\text { organizational growth. }\end{array}$ & 336 & 1.00 & 5.00 & 3.5625 & 1.15731 \\
\hline $\begin{array}{l}\text { Staff not eager to come to work most of the } \\
\text { time. }\end{array}$ & 336 & 1.00 & 5.00 & 3.6964 & 1.50723 \\
\hline $\begin{array}{l}\text { Social activities is considered a part of } \\
\text { organizational culture. }\end{array}$ & 336 & 1.00 & 5.00 & 2.0476 & 1.29895 \\
\hline $\begin{array}{l}\text { I feel like the management team here is not } \\
\text { transparent. }\end{array}$ & 336 & 1.00 & 5.00 & 4.3929 & .73737 \\
\hline Managers give each other respect. & 336 & 1.00 & 5.00 & 4.2232 & 1.11470 \\
\hline $\begin{array}{l}\text { I have been spoken about my personal } \\
\text { development in last six months. }\end{array}$ & 336 & 1.00 & 5.00 & 3.9613 & 1.01701 \\
\hline $\begin{array}{l}\text { Reward and compensation is not in tandem } \\
\text { with job done. }\end{array}$ & 336 & 1.00 & 5.00 & 4.0298 & 1.15862 \\
\hline $\begin{array}{l}\text { Reward and compensation is worse than in } \\
\text { other firms. }\end{array}$ & 336 & 1.00 & 5.00 & 4.2917 & .90342 \\
\hline $\begin{array}{l}\text { Work life balance promoted and practiced in } \\
\text { the company. }\end{array}$ & 336 & 1.00 & 5.00 & 3.8333 & .97837 \\
\hline
\end{tabular}


International Journal of Heritage, Tourism and Hospitality Vol. (12), No. (1/2), March, 2018 By: Faculty of Tourism and Hotels, Fayoum University

\begin{tabular}{|l|l|c|c|c|c|c|}
\hline & $\begin{array}{l}\text { The Organization pays additional and excess } \\
\text { cost for announcement, medical, and other } \\
\text { matters when recruiting new employees. }\end{array}$ & 336 & 1.00 & 5.00 & 4.1220 & 1.11167 \\
\hline $\begin{array}{l}\text { There is a high moral among members of the } \\
\text { organization. }\end{array}$ & 336 & 1.00 & 5.00 & 2.0149 & 1.47509 \\
\hline $\begin{array}{l}\text { Management try their best to ensure that } \\
\text { employees will not leave the organization. }\end{array}$ & 336 & 1.00 & 5.00 & 2.9762 & .93331 \\
\hline Total & & & & 3.659 & 1.1868 \\
\hline
\end{tabular}

As shown in table 2, Respondents "Agreed" (item scores item scores between 4.49 - 3.50) with fourteen of the items included in the scale which represent $64 \%$ of total scale contribution "leadership and organizational culture causes". The items with which they most strongly agreed were "Managers acknowledge employees' contributions, Managers do not provide constructive feedback during the appraisal, Managers treat employees equally, Managers maintain a professional relationship with employees,

My values are aligned with the organization's culture, staff development considered with the organizational growth, staff not eager to come to work most of the time, I feel like the management team here is not transparent, Managers give each other respect, I have been spoken about my, personal development in last six months, Reward and compensation is not in tandem with job done, Reward and compensation is worse than in other firms, Work life balance promoted and practiced in the company, and The Organization pays additional and excess cost for announcement, medical, and other matters when recruiting new employees."

These items indicated that employees are satisfied about the managers' performance. On contrary they are dissatisfied from the lack of management transparent, and employees' motivation. Employees selected two of the items included in the scale "leadership and organizational culture causes classified as: Neither Agree nor Disagree 3.49 - 2.51".

"Management tries their best to ensure that employees will not leave the organization, and Managers have sufficient knowledge of the job"

Respondents "strongly disagreed" (item scores 1.51 or less) with one of the items included in the scale "individual causes satisfaction. The items with which they most strongly agreed were "My manager doesn't keep me well informed on work issues."

In addition, employees "disagreed" (item scores between 2.5 - 1.51) with five of the twenty-two Items used to personal reasons for leakage. "Managers offer and promote all the ways to develop his team, my managers neither listen nor valued my suggestions, my managers use tactful discipline, social activities is considered a part of organizational culture, and there is high morale among members of the organization".

These results revealed that manageress must maintain a good work environment with fair treatment with all employees, and he should be empathy when an employee approaches him. They must personally behave in co-incidence with lush values and beliefs, and they must train. They must threw in one lot with and uphold the culture. With the astuteness of training in today's organizations, and it's ahead of the game full head of steam on employee behavior, leaders in organizations should create a training that supports prosperous moral and ethical behavior. That behavior becomes a powerful way of communicating a front page new, especially if the leaders are totally uninterrupted in their enjoy behavior. It is the character that sends the message practically the leader's priorities, values, and beliefs. It is thus the consistency that is having to do with and not the degree of the action.

The output of table 3 shows that the model summary and overall fit statistics. The results revealed that the adjusted $\mathrm{R}^{2}$ of the model is 0.254 with the $\mathrm{R}^{2}=.256$, this means that the linear 
regression explains $25.6 \%$ of the variance in the data. The adjusted $\mathrm{R}^{2}$ corrects the $\mathrm{R}^{2}$ for the number of independent variables in the analysis, thus it helps detect over-fitting, because every new independent variable in a regression model always explains a little additional bit of the variation, which increases the $\mathrm{R}^{2}$. The Durbin-Watson $\mathrm{d}=.509$ is between the two critical values of $.50<\mathrm{d}<2.39$, therefore we can assume that there is no first order linear autocorrelation in the data.

Table 3. Model Summary

\begin{tabular}{|c|c|c|c|c|c|c|c|c|c|c|}
\hline \multirow[t]{2}{*}{ Model } & \multirow[t]{2}{*}{$\mathrm{R}$} & \multirow{2}{*}{$\begin{array}{c}\mathrm{R} \\
\text { Square }\end{array}$} & \multirow{2}{*}{$\begin{array}{l}\text { Adjusted } \\
\text { R Square }\end{array}$} & \multirow{2}{*}{$\begin{array}{c}\text { Std. } \\
\text { Error of } \\
\text { the } \\
\text { Estimate }\end{array}$} & \multicolumn{5}{|c|}{ Change Statistics } & \multirow{2}{*}{$\begin{array}{l}\text { Durbin } \\
\text { Watson }\end{array}$} \\
\hline & & & & & $\begin{array}{c}\text { R Square } \\
\text { Change }\end{array}$ & $\begin{array}{c}\mathrm{F} \\
\text { Change }\end{array}$ & df1 & $\mathrm{df} 2$ & $\begin{array}{c}\text { Sig. F } \\
\text { Change }\end{array}$ & \\
\hline 1 & .506 & .256 & .254 & 6.19031 & .256 & 114.903 & 1 & 334 & .000 & .509 \\
\hline
\end{tabular}

The results of table 4 explained that the linear regression analysis estimates the linear regression function to be $\mathrm{y}=49.872+.346^{*} \mathrm{x}$. This means that an increase in one unit of $\mathrm{x}$ results in an increase of .346 units of $y$. The test of significance of the linear regression analysis tests the Hypothesis that the estimated coefficient is 0 . The t-test found that both intercept and variable are highly significant $(\mathrm{p}<0.001)$ and thus we might say that they are significantly different from zero. This result confirms Hypothesis 3 "Managerial leakage causes influenced by the individual leakage causes.

Table 4. Coefficients

\begin{tabular}{|c|c|c|c|c|c|c|c|c|c|c|}
\hline \multirow{2}{*}{ Model } & \multicolumn{2}{|c|}{$\begin{array}{l}\text { Unstandardize } \\
\text { d Coefficients }\end{array}$} & \multirow{2}{*}{$\begin{array}{c}\begin{array}{c}\text { Standardized } \\
\text { Coefficients }\end{array} \\
\text { Beta }\end{array}$} & \multirow{2}{*}{$\mathrm{t}$} & \multirow{2}{*}{ Sig. } & \multicolumn{2}{|c|}{$\begin{array}{l}95 \% \text { Confidence } \\
\text { Interval for B }\end{array}$} & \multicolumn{3}{|c|}{ Correlations } \\
\hline & B & $\begin{array}{l}\text { Std. } \\
\text { Error }\end{array}$ & & & & $\begin{array}{l}\text { Lower } \\
\text { Bound }\end{array}$ & $\begin{array}{l}\text { Upper } \\
\text { Bound }\end{array}$ & $\begin{array}{l}\text { Zero- } \\
\text { order }\end{array}$ & $\begin{array}{c}\text { Partia } \\
1\end{array}$ & $\begin{array}{c}\text { Par } \\
\mathrm{t}\end{array}$ \\
\hline (Constant) & 49.8 & 2.414 & & 20.6 & .00 & 45.12 & 54.62 & & & \\
\hline managerial & .346 & .032 & .506 & 10.7 & .00 & .283 & .410 & .506 & .506 & .50 \\
\hline $\begin{array}{r}\text { a. Depend } \\
\text { indi }\end{array}$ & $\begin{array}{l}\text { Vari } \\
\text { ual }\end{array}$ & & & & & & & & & \\
\hline
\end{tabular}

\section{Discussions}

Mean and standard deviation analysis

Respondents "Agreed" (item scores item scores between 4.49 - 3.50) with sixteen of the items included in the scale which represent $73 \%$ of total scale contribution "individual causes satisfaction". These results indicated that salary, mismanagement, and benefits are the major concern of employees to leave or stay in their job. The pervious results revealed that employees are not satisfied with their development plan in three star hotels, and they just stay in their job because they don't have any another options. In addition, they think that there's fairness in work load distribution, but the load itself is too much. This may be due to less of the hiring staff instead of the people who left.

Employees "strongly disagree to disagreed" (item scores between 2.5 - 1.51) with six of the twenty-two Items used to personal reasons for leakage. These results revealed that payoff management should consider the process of design and implementing strategies to reward employee fairly with the goal to attract, motivate, and retain those employees that are believed to help facilitate the recognition of hotel goals. Moreover, upper management should permits subordinates to take part in decision-making and gives them a considerable degree of autonomy in completing routine work activities. Combining between democratic (subordinates are allowed 
to participate in decision-making) and directive (subordinates are told exactly how to do their jobs) styles gives management distinct ways to manage and increase employees satisfaction which limit the leakage rate.

Respondents "Agreed" (item scores item scores between 4.49 - 3.50) with fourteen of the items included in the scale which represent $64 \%$ of total scale contribution "leadership and organizational culture causes". These results indicated that employees are satisfied about the managers' performance. On contrary they are dissatisfied from the lack of management transparent, and employees' motivation".

Employees "strongly disagree to disagreed" (item scores between 2.5 - 1.51) with six of the twenty-two Items used to personal reasons for leakage. These results revealed that manageress must maintain a good work environment with fair treatment with all employees, and they should be empathy when an employee approaches him. They must personally behave in co-incidence with lush values and beliefs, and they must train, others racket the same. They must threw in one lot with and uphold the culture. With the astuteness of training in today's organizations, and it's ahead of the game full head of steam on employee behavior, leaders in organizations should create a training that supports prosperous moral and ethical behavior. That behavior becomes a powerful way of communicating a front page new, especially if the leaders are totally uninterrupted in their enjoy behavior.

The character sends the message practically the leader's priorities, values, and beliefs. It is thus the consistency that is having to do with and not the degree of the action.

Regression

The results revealed that the adjusted $\mathrm{R}^{2}$ of the model is 0.254 with the $\mathrm{R}^{2}=.256$. This means that the linear regression explains $25.6 \%$ of the variance in the data. The adjusted $\mathrm{R}^{2}$ corrects the $\mathrm{R}^{2}$ for the number of independent variables in the analysis, thus it helps detect over-fitting, because every new independent variable in a regression model always explains a little additional bit of the variation, which increases the $\mathrm{R}^{2}$. The Durbin-Watson $\mathrm{d}=.509$ is between the two critical values of $.50<\mathrm{d}<2.39$.

The regression coefficients, the intercept, and the significance of all coefficients and the intercept in the model. The results explained that the linear regression analysis estimates the linear regression function to be $y=49.872+.346^{*} \mathrm{x}$. This means that an increase in one unit of $\mathrm{x}$ results in an increase of .346 units of $y$. The test of significance of the linear regression analysis tests the Hypothesis that the estimated coefficient is 0 . The t-test found that both intercept and variable are highly significant $(\mathrm{p}<0.001)$ and thus we might say that they are significantly different from zero. This result confirms Hypothesis 3 "Managerial leakage are influenced by the individual leakage causes".

In summary, this study investigated the relationship between the managerial causes of leakage and the individual causes of leakage, and The correlation analysis found a high positive correlation between the two variables $(r=0.506)$. We then conducted a simple regression analysis to further substantiate the suspected relationship. The estimated regression model is individual cause $=49.872+.346^{*}$ managerial causes with an adjusted $\mathrm{R}^{2}$ of $25.6 \%$; it is highly significant with $\mathrm{p}<0.001$ and $\mathrm{F}=114.903$. The standard error of the estimate is 6.19031 .

Thus, result can not only show a positive linear relationship, and we can also conclude that for every additional individual cause the managerial cause will increase by approximately .346units. 


\section{Conclusion and recommendations}

The relationship between individual satisfaction and managerial Leakage has been considered, as we all know if we try to increasing job satisfaction, then we will reduce job Leakage somehow partly. So in this part we will bring forward some recommendation for increasing job satisfaction and reduce employee leakage in three star hotels. The higher the leakage, the more pressure placed on recruiting. Several recommendations for controlling employee leakage in three star hotels are shown below.

1. Establishing program to facilitate decrease staff leakage of the three star hotels. A career development plan may also facilitate the career development discussion. Acknowledge the abilities and talents that the worker has gained which can create them eligible for subsequent advancement.

2. Human recourses management should offer a link between the employees' job and therefore the success of the small- and- medium -sized properties. It offers workers a way of stability of the organization as a result of the staff will see that somebody is responsible and worrying regarding the massive image.

3. Managers should concentrate more on worker concepts and complaints as necessary side of communication. Workers don't feel be listened to are de-motivated.

4. Upper management should create a system of often scheduled one-on-one conferences between the worker and manager. This will facilitate fill the necessity to be listened to.

5. Human recourses management should maintain The Performance Management method. taking note of workers offers them a message that they're valued and provides them with a way of management over their work

6. Providing recognition to workers could be a third side of communication. Forms of recognition will vary from a straightforward "thank you for employment well done," to a plaque, to monetary incentives. Recognitions mean what use do are recognized by others particularly the supervisors, and each one are phrased after they contribute to their work, which can produce an awfully snug work setting.

7. The management ought to improve the operating condition for the workers love flexibility in choice of shifts and equalization of labor and private life for the workers.

8. Employees should not be overworked with little or no compensation as this may cause demotivation and therefore demoralization. The study suggested that, the management ought to improve the interior operating atmosphere thus on retain additional staff. After, coaching policies in addition as creation of versatile operating hours would encourage additional staff to look at hotels jobs as future careers like in alternative industries.

\section{References}

Bolch, M. (2001).The coming Crunch; Human Resource Training Magazine, April 196(2628), 42-46.

Carley, K. (1992). Organizational learning and personnel turnover.Organ. Sci.3 (1) 20-46.

Cascio, W. (2002). Responsible Restructuring: Creative and Profitable Alternatives to Layoffsi, San Francisco: Berrett-Koehler.

Chiu, C.-K., Lin, C.-P., Tsai, Y. H., \& Hsiao, C.-Y. (2005). Modelling turnover intentions and their antecedents using the locus of control as a moderator: A case of customer service employees. Human Resource Development Quarterly, 16(4), 481-499.

Fortino, P. \&Ninemeier, J. (1996)."Industry in the dark about turnover rate", Lodging, Vol. 22 (No.4), pp. 25.

Gall, M. D., Gall, J. P., \& Borg, W. R. (2006). Educational research: An introduction (8th Ed.). Pearson Education Inc. ISBN-10: 0205488498. 
Glebbeek, A.C., Bax, E.H. (2004). Is high employee turnover really harmful; An empirical test using company records, Academy of Management Journal, Vol. 47 (No.2), pp.86-277.

Gregory, R.J. (2014). Psychological Testing: History, Principles and Applications. (8th Ed.). Allyn and Bacon: Boston.

Gupta, N. and Shaw, J. (2001). Pay fairness and Employee outcomes. Exacerbation and attenuation effects of financial needs.Journal of Occupational and Organizational Psychology Vol 74 (3), pp 22.

Hilton Hotels Corporation Journal (2003). Vol. 1, No. 6, pp 8-12.

Hinkin,T.R\&Tracey,J.B. (2000). The cost of turnover, The Cornell HRA Quarterly .page 14-21.

Judge, T. A., Thoresen, C. J., Bono, J. E., \& Patton, G. K. (2001). The job satisfaction-job performance relationship: A qualitative and quantitative review. Psychological Bulletin.

Kusluvan, S. (2003). Multinational enterprises in tourism; A case study of Turkey. Unpublished doctoral dissertation, Strathclyde University, the Scottish Hotel School, Glascow.

Mugenda, O.M and Mugenda, A.G (2008). Research Methods, Quantitative \& Qualitative Approaches, Acts Press, Nairobi.

Ready, D. A., Hill, L. A., \& Conger, J. A. (2008).Winning the Race for Talent in Emerging Markets. Nov 2008. Harvard Business Review.

Sahinidis, G., and Bouris, J. (2008). "Employee perceived training effectiveness relationship to employee attitudes". Journal of European Industrial Training, 32(1), 63-76.

Schermerholn, JR. (1996). Essentials of management and organizational behavior, NY: John Wiley and Sons, New York.

Tanke, ML. (2001). Human Resources Management for the Hospitality Industry, 2nd ed., Thomson Learning, Albany, NY.

Taylor, S. (2002). People and Organization Employee Resourcing.Prentice-Hall, Sidney; Australia.

Van Dick, R., Christ, O., Stellmacher, J., Wagner, U., Ahlswede, O.,

Grubba, C., Hauptmeier, M., Hohfeld, C., Moltzen, K., \&Tissington, P. A. (2004). Should I stay or should I go? Explaining turnover intentions with organizational identification and job satisfaction.British Journal of Management, 15, 351- 360.

WeiBo, Z., Kaur, S., \&Zhi, T. (2010). A critical review of employee turnover model (1938-2009) and development in perspective of performance.African journal of Business Management, 4(19), 4146-4158.

White, G.L (1995). Employee turnover; the hidden drain on profits; HR Focus, Vol.72 (No.1) pp.15-17.

Willis, M. (2002). 'Reducing Employee Turnover', Creating Quality Newsletter, Vol. 11, No. 5, viewed 25 October 2016, http://www.missouribusiness.net/cq/2002/reducing_employee_turnover.asp.

Woods, R H (1999). 'Predicting is difficult, especially about the future: human resources in the new millennium', International Journal of Hospitality.

Zuber, A. (2001). "A career in food service cons: high turnover", Nations Restaurant News, Vol. 35 (No.21), pp.147-148. 